\begin{tabular}{|c|c|c|}
\hline BIODIK & $\begin{array}{c}\text { BIODIK: Jurnal IImiah Pendidikan Biologi } \\
\text { ISSN 2580-0922 (online), ISSN 2460-2612 (print) } \\
\text { Volume 6, Nomor 02, Tahun 2020, Hal. 133-144 } \\
\text { Available online at: } \\
\text { https://online-journal.unja.ac.id/biodik }\end{array}$ & BIODIK \\
\hline
\end{tabular}

Research Article

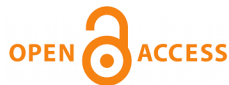

\title{
Pengembangan LKPD Berbasis Inkuiri Terbimbing pada Mata Pelajaran IPA Pokok Bahasan Klasifikasi Mahluk Hidup
}

\section{(Development of Guided Inquiry-based Student Worksheet on Science Subject in the Chapter of Classification of Living Things)}

\begin{tabular}{|c|c|}
\hline \multicolumn{2}{|c|}{$\begin{array}{l}\text { Tantri Margayu1*, Upik Yelianti², Afreni Hamidah }{ }^{3} \\
{ }^{*} \text { SMPN } 10 \text { Kota Jambi, } 2,3 \text { Prodi Pendidikan Biologi PMIPA FKIP Universitas Jambi } \\
\text { JI Taruna Jaya Komplek Tritura Kelurahan Rajawali Jambi Timur-Jambi-Indonesia } \\
{ }^{*} \text { Corresponding Author: tantri.margayu@gmail.com }\end{array}$} \\
\hline Informasi Artikel & ABSTRACT \\
\hline $\begin{array}{l}\text { Submit: } 07-02-2020 \\
\text { Diterima: } 20-05-2020 \\
\text { Dipublikasikan:09-06-2020 }\end{array}$ & $\begin{array}{l}\text { One effort that Teachers can do in order to encourage student } \\
\text { engagement in class is by selecting media which enable students to } \\
\text { practice their skills on doing experiments, critical thinking skills so } \\
\text { that they could develop science concept. The purpose of this } \\
\text { research is to produce Guided Inquiry-based Student Worksheet on } \\
\text { Science Subject in the Chapter of Classification of Living Things, } \\
\text { students and teacher perception on the worksheet are also sought. } \\
\text { The developmental research uses ADDIE model. Worksheet as the } \\
\text { product was put on trial prior to the validation processes. Media and } \\
\text { material validation of the worksheet resulted in the percentage of } \\
98.75 \% \text { and } 90.00 \% \text { respectively, indicating both are categorised as } \\
\text { "Very Good". As for the small and large group testing, the } \\
\text { percentage of 93.05\% and } 86.25 \% \text { are obtained respectively, } \\
\text { indicating both are categorised as "Very Good". The percentage of } \\
97.72 \text { is obtained from the teachers' perception, indicating it is } \\
\text { categorised as "Very Good". Based on the results of the study, a } \\
\text { conclusion could be made that the Guided Inquiry-based Student } \\
\text { Worksheet on Science Subject in the Chapter of Classification of } \\
\text { Living Things is appropriate to be used in learning. } \\
\text { Keywords: Student worksheet, Guided Inquiry, Classification of } \\
\text { living things }\end{array}$ \\
\hline Penerbit & ABSTRAK \\
\hline $\begin{array}{l}\text { Program Studi Pendidikan } \\
\text { Biologi, Fakultas Keguruan dan } \\
\text { Ilmu Pendidikan, Universitas } \\
\text { Jambi }\end{array}$ & $\begin{array}{l}\text { Salah satu upaya guru agar peserta didik berperan aktif dalam } \\
\text { pembelajaran adalah dengan memilih media yang dapat melatih } \\
\text { keterampilan melakukan eksperimen, meningkatkan keterampilan } \\
\text { berpikir kritis sehingga peserta didik dapat mengembangkan konsep } \\
\text { IPA. Salah satunya adalah dengan menggunakan media LKPD } \\
\text { berbasis inkuiri terbimbing. Penelitian ini bertujuan menghasilkan } \\
\text { LKPD berbasis inkuiri terbimbing pada pokok bahasan klasifikasi } \\
\text { mahluk hidup, juga untuk mengetahui persepsi peserta didik dan } \\
\text { guru terhadap LKPD yang dikembangkan. Penelitian ini merupakan } \\
\text { penelitian pengembangan dengan model pengembangan ADDIE. } \\
\text { Produk LKPD sebelum diujicobakan terlebih dahulu divalidasi oleh } \\
\text { ahli media dan ahli materi. Hasil validasi media diperoleh nilai } \\
\text { persentase } 98,75 \% \text { dengan katagori sangat baik,dan validasi materi } \\
\text { diperoleh nilai persentase } 90,00 \% \text { dengan katagori sangat baik. } \\
\text { Hasil uji coba kelompok kecil dan uji coba kelompok besar secara } \\
\text { berurutan adalah } 93,05 \% \text { dan } 86,25 \% \text {, keduanya termasuk dalam } \\
\text { katagori sangat baik. Selanjutnya untuk persepsi guru diperolah }\end{array}$ \\
\hline
\end{tabular}


Kata kunci: LKPD, Inkuiri terbimbing, Klasifikasi mahluk hidup

This BIODIK : Jurnal IImiah Pendidikan Biologi is licensed under a CC BY-NC-SA (Creative Commons Attribution-ShareAlike 4.0 International License)

\section{PENDAHULUAN}

Belajar merupakan proses pencapaian kompetensi pengetahuan, sikap dan keterampilan. Belajar merupakan perubahan sikap dari peserta didik (Sadikin,A, 2015). Karena IPA berhubungan dengan cara mencari tahu tentang alam secara sistematis, maka belajar IPA bukan hanya belajar tentang kumpulan pengetahuan yang berupa fakta-fakta, konsp-konsep, atau prinsip-prisnsip saja tetapi juga merupakan suatu proses penemuan (Zubaidah, dkk., 2017). Untuk mencapai hal tersebut diperlukan peran guru sebagai pengarah pembelajaran sehingga peserta didik dapat menemukan dan merekontruksi pengetahuannya kembali, serta pembelajaran tidak hanya berpusat pada guru tetapi pada peserta didik. Untuk mencapai berbagai hal tersebut guru perlu melakukan berbagai upaya salah satunya pemilihan media. Media memiliki berbagai manfaat pada proses pembelajaran antara lain dapat menjelaskan materi pembelajaran atau obyek yang abstrak (tidak nyata) menjadi konkrit (nyata), memberikan pengalaman nyata dan langsung, menarik perhatian peserta didik, lebih mudah diingat dan diungkapkan kembali, serta mempermudah dan mempercepat guru menyajikan materi pembelajaran.(Sumiati dan Asra, 2007).

Berdasarkan penyebaran angket dan wawancara yang dilakukan kepada guru-guru di beberapa SMP di Kota Jambi pada bulan Maret 2018 didapatkan temuan bahwa materi IPA khususnya Biologi yang dirasa sulit untuk dipahami peserta didik salah satunya adalah Klasifikasi Mahluk Hidup, dengan alasan peserta didik sulit memahami istilah-istilah ilmiah dan karakteristik (ciri khusus) mahluk hidup. Rata-rata nilai ulangan harian pada pokok bahasan tersebut masih di bawah 70 nilai KKM (Kriteria Ketuntasan Maksimal). Dari 6 kelas yang ada diambil nilai ulangan 4 kelas didapat hasil bahwa kelas $7 \mathrm{~A}$ rata-rata nilai ulangan 52,97 dengan jumlah peserta didik yang tuntas 6 orang (18,18\%), kelas 7B rata-rata nilai ulangan 51,58 dengan jumlah peserta didik yang tuntas 10 orang $(30,30 \%)$, kelas $7 \mathrm{C}$ rata-rata nilau ulangan 50,61 dengan jumlah peserta didik yang tuntas 7 orang $(21,21 \%)$, dan kelas 7D rata-rata nilai ulangan 52,91 dengan jumlah peserta didik yang tuntas 7 orang $(21,21 \%)$. Salah satu usaha untuk mencapai tujuan pembelajaran yang efektif dan efisien dapat dilakukan dengan pengembangan LKPD IPA yang lebih berkualitas dengan menggunakan model pembelajaran yang mampu menuntut keterlibatan peserta didik aktif dalam proses pembelajaran seperti model inquiri. Eggen dan Kauchack (2012) menyatakan bahwa model inkuiri merupakan salah satu cara efektif yang dapat membantu peserta didik meningkatkan keterampilan berpikir dengan menggunakan proses mental lebih tinggi dan keterampilan berpikir kritis. Model inkuiri yang cocok diterapkan pada peserta didik Sekolah Menengah Pertama (SMP) 
adalah inkuiri terbimbing, karena menurut Madlazim (2015:) pada inkuiri terbimbing peserta didik diberikan bimbingan terlebih dahulu untuk melakukan aktivitas belajar seperti eksperimen. Menurut Putri dan Widiyatmoko (2013) peserta didik merasa senang apabila LKPD digunakan saat pembelajaran di kelas karena membuat mereka mengerti cara merancang percobaan IPA dengan langkah percobaan yang sederhana, mudah dipahami, dan mudah dilaksanakan. LKPD dapat meningkatkan keterampilan proses sains peserta didik (Dewi, R., Budiarti, R. S., \& Aina, M, 2017).

LKPD berbasis pendekatan inkuiri terbimbing diharapkan dapat digunakan guru sebagai sarana untuk melatih keterampilan melakukan eksperimen, meningkatkan keterampilan berpikir kritis sehingga peserta didik dapat mengembangkan konsep IPA. Hal ini sejalan dengan penelitian yang dilakukan oleh Nuraini (2014), bahwa dengan menggunakan LKPD berbasis inkuiri terbimbing peserta didik menjadi aktifmdalam proses pembelajaran dan dapat mengkontruksi pemahamannya sendiri. Oleh karena itu perlu untuk melakukan penelitian pengembangan LKPD cetak yang berjudul "Pengembangan Lembar Kerja Peserta Didik (LKPD) Berbasis Inkuiri Terbimbing pada Mata Pelajaran IPA Pokok Bahasan Klasifikasi Mahluk Hidup untuk Peserta Didik Kelas VII SMP". Tujuan penelitian ini adalah; 1) Mengembangkan bahan ajar IPA dalam bentuk LKPD berbasis Inkuiri Terbimbing pada pokok bahasan klasifikasi mahluk hidup untuk peserta didik kelas VII SMP. 2) Mengetahui kelayakan pada produk hasil pengembangan LKPD berbasis Inkuiri Terbimbing pada pokok bahasan klasifikasi mahluk hidup untuk peserta didik kelas VII SMP. 3) Mengetahui persepsi guru dan peserta didik terhadap produk hasil pengembangan LKPD berbasis Inkuiri Terbimbing pada pokok bahasan klasifikasi mahluk hidup untuk peserta didik kelas VII SMP.

\section{METODE PENELITIAN}

Penelitian pengembangan LKPD ini menggunakan model ADDIE (Analysis, Design, Development or Production, Implementation or Delivery and Evaluations). Prosedur pengembangan yang digunakan dalam penelitian ini mengadaptasi model ADDIE, namun hanya sampai tahap development.

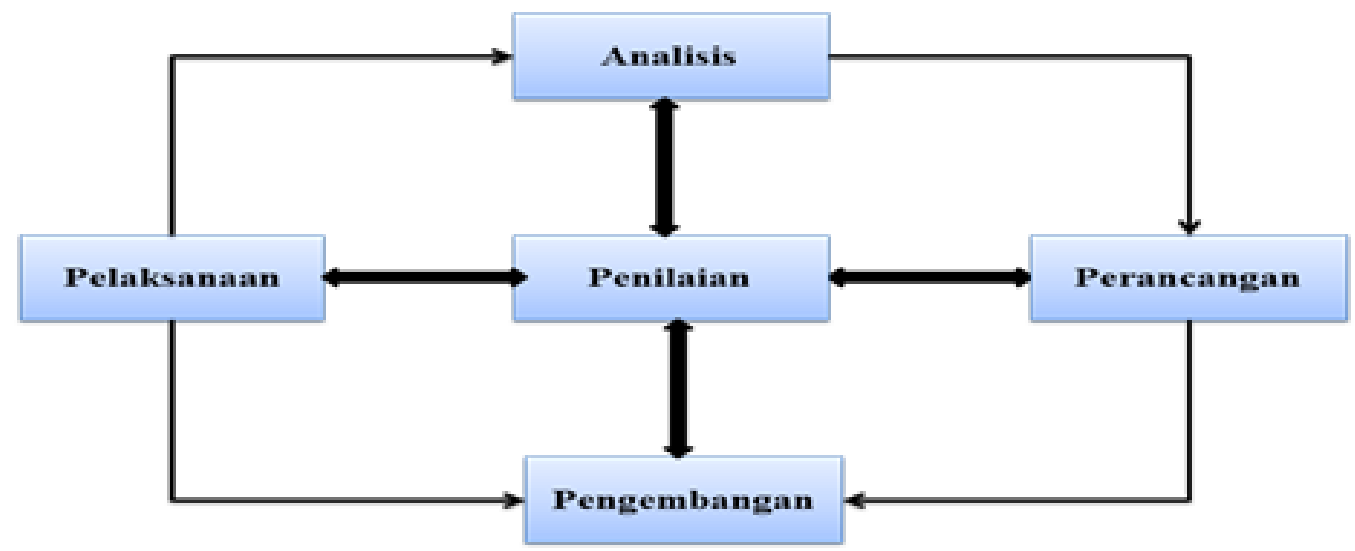

Gambar 1. Model Pengembangan ADDIE (Branch, 2009)

Analisis kebutuhan dilakukan dengan tujuan untuk mengetahui permasalahan apa yang dihadapi sehingga dapat mengidentifikasi poin-poin penting yang menjadi 
kebutuhan peserta didik maupun guru, Analisis dilakukan dengan menyebarkan angket kepada beberapa guru SMP Negeri di kota Jambi dalam forum musyawarh guru Mata Pelajaran (MGMP) IPA Rayon 1 Kota Jambi. Wawancara juga dilakukan pada guru yang mengajar IPA dan beberapa orang peserta didik kelas VIII di SMPN 10 Kota Jambi. Analisis Kurikulum dilakukan terhadap silabus dan RPP yang digunakan guru dalam pembelajaran IPA. Hasil analisis digunakan sebagai pedoman dalam menentukan konsep dan konten yang sesuai dalam media yang akan dikembangkan. Selanjutnya, dilakukan analisis RPP untuk mengetahui model dan metode pembelajaran yang digunakan serta media pendukung pembelajaran yang digunakan. Tahap desain (Design) pada pengembangan LKPD ini meliputi penentuan jadwal pembuatan produk, pengumpulan bahan, serta pembuatan produk. Pada tahap ini juga ditentukan tim kerja, serta spesifiaksi produk. Tim kerja terdiri dari penulis dan pembimbing sebagai pengembang produk, tim ahli untuk validasi produk yang terdiri dari ahli media dan ahli materi. Tahap pengembangan (Development), merupakan tahap pembuatan LKPD meliputi; pengumpulan materi, gambar kontekstual yang berkaitan dengan klasifikasi mahluk hidup dan penyusunan materi klasifikasi makluk hidup, serta validasi media dan validasi materi oleh tim ahli. Selanjutnya dilakukan uji coba produk LKPD yang sudah dibuat. Ujicoba produk dilakukan pada guru IPA (2 orang), kelompok kecil (6 siswa) dan kelompok besar (20 siswa).

Untuk melihat kevalidan produk maka diadakan penilaian produk oleh ahli. Adapun instrumen lembar angket validasi materi menggunakan kisi-kisi yang dapat dilihat pada tabel 1. Data penilaian ahli materi digunakan sebagai acuan dalam merevisi LKPD yang dikembangkan hingga diperoleh LKPD yang layak. LKPD yang sudah lulus validasi akan digunakan dalam pembelajaran.

Tabel 1. Kisi - kisi validasi materi

\begin{tabular}{|c|c|c|}
\hline No. & $\begin{array}{l}\text { Aspek yang } \\
\text { diamati }\end{array}$ & Butir pernyataan \\
\hline 1 & Aspek isi & $\begin{array}{l}\text { Petunjuk penggunaan LKPD untuk guru dan peserta didik sudah } \\
\text { sesuai } \\
\text { Judul percobaan pada LKPD sudah sesuai dengan indikator } \\
\text { Teori singkat/fenomena yang disajikan pada LKPD sesuai dengan } \\
\text { KI/KD/indikator } \\
\text { Materi pada LKPD sesuai dengan indikator dan tujuan pembelajaran } \\
\text { Kedalaman materi pada LKPD sesuai dengan KI/KD/Indikator } \\
\text { LKPD memiliki keutuhan konsep pembelajaran pada materi } \\
\text { Klasifikasi Mahluk Hidup } \\
\text { LKPD logis jika digunakan dalam proses pembelajaran IPA di } \\
\text { sekolah } \\
\text { LKPD runut dalam penyajian alur proses dan informasi }\end{array}$ \\
\hline 2 & $\begin{array}{l}\text { Aspek } \\
\text { penyajian }\end{array}$ & $\begin{array}{l}\text { LKPD memiliki format yang konsisten dalam penyajiannya } \\
\text { LKPD memiliki penjelasan yang relevan terhadap materi Klasifikasi } \\
\text { Mahluk Hidup } \\
\text { Tahap kegiatan pada LKPD sudah sesuai dengan model inkuiri } \\
\text { terbimbing } \\
\text { Kegiatan yang disajikan menumbuhkan rasa ingin tahu peserta didik } \\
\text { Penyajian LKPD dilengkapi dengan gambar dan lustrasi }\end{array}$ \\
\hline 3 & Aspek bahasa & $\begin{array}{l}\text { Bahasa yang digunakan sesuai dengan tingkat pemahaman peserta } \\
\text { didik } \\
\text { Kalimat yang digunakan jelas dan mudah dimengerti }\end{array}$ \\
\hline
\end{tabular}


BIODIK: Jurnal IImiah Pendidikan Biologi

Vol. 06, No. 02 (2020), Hal. $28-39$

Adapun instrumen lembar angket validasi media menggunakan kisi-kisi yang dapat dilihat pada tabel 2. Data penilaian ahli media digunakan sebagai acuan dalam merevisi LKPD yang dikembangkan hingga diperoleh LKPD yang layak. LKPD yang sudah lulus validasi akan digunakan dalam pembelajaran.

Tabel 2, Kisi-kisi validasi media

\begin{tabular}{|c|c|c|}
\hline No & $\begin{array}{c}\text { Aspek yang } \\
\text { diamati }\end{array}$ & Butir pernyataan \\
\hline 1 & $\begin{array}{l}\text { Kelayakan } \\
\text { kegrafikan }\end{array}$ & $\begin{array}{l}\text { Desain fisik cover sudah didesain dengan baik } \\
\text { Desain halaman LKPD sudah didesain dengan baik } \\
\text { Bentuk LKPD sudah ditetapkan sesuai dengan materi yang akan } \\
\text { diajarkan } \\
\text { Lay out dan tata letak LKPD sudah didesain dengan menarik } \\
\text { Pemilihan warna pada LKPD sudah ditentukan dengan baik } \\
\text { Objek yang disajikan dalam LKPD dapat mewakili konsep materi dan } \\
\text { didesain dengan baik } \\
\text { Penggunaaan ilustrasi grafis sudah tepat dan baik } \\
\text { Gambar sudah sesuai dengan materi } \\
\text { Desain ilustrasi sudah menarik dan komunikatif } \\
\text { Konsistensi penggunaan spasi, judul, dan pengetikan materi sudah } \\
\text { benar dan tepat } \\
\text { LKPD sudah dirancang dengan tata letak yang menarik, mudah dibaca } \\
\text { dan digunakan } \\
\text { Kesesuaian penggunaaan variasi jenis, ukuran dan bentuk huruf dalam } \\
\text { LKPD sudah benar dan menarik }\end{array}$ \\
\hline 2 & $\begin{array}{l}\text { Kelayakan } \\
\text { penyajian }\end{array}$ & $\begin{array}{l}\text { Urutan penyajian LKPD sudah jelas dan runut } \\
\text { Desain setiap kegiatan yang disajikan mempunyai tujuan yang jelas } \\
\text { Kesinambungan transisi halaman sudah baik dan benar penulisannya } \\
\text { Kemudahan membaca teks atau tulisan sudah didesain dengan baik } \\
\text { Kejelasan petunjuk atau arahan sudah tepat dan baik }\end{array}$ \\
\hline 3 & $\begin{array}{l}\text { Kelayakan } \\
\text { bahasa }\end{array}$ & $\begin{array}{l}\text { Bahasa yang digunakan sudah sesuai dengan kaidah EYD } \\
\text { Bahasa yang digunakan komunikatif dan interaktif } \\
\text { Bahasa yang digunakan mudah dipahami peserta didik }\end{array}$ \\
\hline
\end{tabular}

Lebih lanjut, Produk berupa LKPD yang sudah dinyatakan valid oleh ahli media dan ahli materi akan diujicobakan kepada guru dan peserta didik. Hal tersebut dilakukan untuk melihat respon guru dan peserta didik terhadap penggunaan LKPD yang sedang dikembangkan. Adapun kisi-kisi angket respon guru terhadap LKPD dapat dilihat pada tabel 3.

Tabel 3. Kisi-kisi Angket Respon Guru terhadap LKPD

\begin{tabular}{lll}
\hline No & $\begin{array}{c}\text { Aspek yang } \\
\text { diamati }\end{array}$ & \multicolumn{1}{c}{ Butir pernyataan } \\
\hline 1 & Aspek & Materi dalam LKPD disajikan secara sistematis, logis, dan sederhana \\
& penyajian & Materi dalam LKPD sesuai dengan perkembangan peserta didik \\
& & Kegiatan yang disajikan dalam LKPD mempunyai tujuan yang jelas dan \\
& sesuai dengan tuntutan indikator pencapaian kompetensi \\
& Penyajian LKPD dilengkapi dengan gambar dan ilustrasi yang relevan \\
& dengan materi yang disajikan \\
& LKPD mampu menarik perhatian dan minat peserta didik untuk \\
& mengerjakan dan mempelajarinya \\
& Peserta didik mudah untuk memahami petunjuk dan arahan dalam \\
& LKPD \\
& Kegiatan dalam LKPD sudah sesuai dengan tahapan model \\
& pembelajaran inkuiri terbimbing \\
& LKPD ditulis dan disajikan dengan baik \\
& Aspek bahasa \\
& Bahasa yang digunakan dalam LKPD sesuai dengan EYD \\
& Bahasa yang digunakan dalam LKPD sesuai dengan tingkat \\
& perkembangan siswa & \\
& Bahasa yang digunakan dalam LKPD komunikatif dan mudah dipahami
\end{tabular}


BIODIK: Jurnal IImiah Pendidikan Biologi

Vol. 06, No. 02 (2020), Hal. 133 - 144

oleh peserta didik

Bahasa yang digunakan dalam LKPD tidak ambigu, jelas, dan mudah dimengerti

LKPD yang sedang dikembangkan juga akan diuji pada kelompok kecil tahapan ini disebut uji kelompok kecil terhadap pengguna produk yaitu peserta didik. Hal ini dilaksanakan untuk melihat respon peserta didik terhadap penggunaan produk yang sedang dikembangkan. Adapun kisi-kisi angket respon peserta didik terhadap LKPD dapat dilihat pada tabel 4.

Tabel 4. Kisi-kisi Angket Respon Peserta Didik pada Uji Kelompok Kecil terhadap LKPD

\begin{tabular}{|c|c|c|}
\hline No & $\begin{array}{l}\text { Aspek yang } \\
\text { diamati }\end{array}$ & Butir pernyataan \\
\hline 1 & $\begin{array}{l}\text { Aspek } \\
\text { penyajian }\end{array}$ & $\begin{array}{l}\text { Petunjuk atau arahan dalam LKPD mudah dipahami } \\
\text { Isi yang disajikan dalam LKPD membuat Anda tertarik untuk mempelajari } \\
\text { dan mengerjakannya } \\
\text { Penyajian materi di dalam LKPD sederhana dan mudah dipahami } \\
\text { Masalah yang disjikan dalam LKPD dapat dipahami } \\
\text { Petunjuk penggunaan LKPD mudah dimengerti } \\
\text { Prosedur kerja dalam LKPD memberikan kemudahan pada peserta didik } \\
\text { dalam memahami materi } \\
\text { LKPD dilengkapi dengan gambar dan ilustrasi sehingga mempermudah } \\
\text { pemahaman Anda } \\
\text { Uraian aambar ielas dan sesuai dengan langkah-lanakah vana disaiikan }\end{array}$ \\
\hline 2 & $\begin{array}{l}\text { Aspek } \\
\text { bahasa }\end{array}$ & $\begin{array}{l}\text { Kalimat yang digunakan jelas dan sederhana } \\
\text { Bahasa yang digunakan jelas dan sederhana } \\
\text { Bahasa yang digunakan dalam LKPD komunikatif dan mudah dipahami } \\
\text { Bahasa yang digunakan dalam LKPD sesuai dengan EYD }\end{array}$ \\
\hline
\end{tabular}

Setelah mendapatkan respon pada kelompok kecil maka dilakukan tahap selanjutnya yaitu tahap ujicoba kelompok besar. Pada tahap ini LKPD yang sedang dikembangkan akan diuji pada kelompok besar untuk mendapatkan respon peserta didik yang lebih banyak dari sebelumnya. Adapun kisi-kisi angket respon peserta didik terhadap LKPD pada kelompok besar dapat dilihat pada tabel 5.

Tabel 5. Kisi-kisi Angket Respon Peserta Didik pada Uji Kelompok Besar terhadap LKPD

\begin{tabular}{|c|c|c|}
\hline No & $\begin{array}{c}\text { Aspek yang } \\
\text { diamati }\end{array}$ & Butir pernyataan \\
\hline 1 & $\begin{array}{l}\text { Aspek } \\
\text { penyajian }\end{array}$ & $\begin{array}{l}\text { Petunjuk atau arahan dalam LKPD mudah dipahami } \\
\text { Isi yang disajikan dalam LKPD membuat Anda tertarik untuk mempelajari } \\
\text { dan mengerjakannya } \\
\text { Penyajian materi di dalam LKPD sederhana dan mudah dipahami } \\
\text { Masalah yang disjikan dalam LKPD dapat dipahami } \\
\text { Petunjuk penggunaan LKPD mudah dimengerti } \\
\text { Prosedur kerja dalam LKPD memberikan kemudahan pada peserta didik } \\
\text { dalam memahami materi } \\
\text { LKPD dilengkapi dengan gambar dan ilustrasi sehingga mempermudah } \\
\text { pemahaman Anda } \\
\text { Uraian gambar ielas dan sesuai dengan langkah-langkah vana disaiikan }\end{array}$ \\
\hline 2 & $\begin{array}{l}\text { Aspek } \\
\text { bahasa }\end{array}$ & $\begin{array}{l}\text { Kalimat yang digunakan jelas dan sederhana } \\
\text { Bahasa yang digunakan jelas dan sederhana } \\
\text { Bahasa yang digunakan dalam LKPD komunikatif dan mudah dipahami } \\
\text { Bahasa yang digunakan dalam LKPD sesuai dengan EYD }\end{array}$ \\
\hline 3 & $\begin{array}{l}\text { Aspek } \\
\text { kegrafikan }\end{array}$ & $\begin{array}{l}\text { Desain fisik cover sudah didesain dengan baik } \\
\text { Pemilihan warna pada LKPD sudah ditentukan dengan baik } \\
\text { Gambar sudah sesuai dengan materi } \\
\text { Kesesuaian penggunaaan variasi jenis, ukuran dan bentuk huruf dalam } \\
\text { LKPD sudah sesuai dan menarik } \\
\text { LKPD sudah dirancang dengan tata letak yang menarik, mudah dibaca } \\
\text { dan digunakan }\end{array}$ \\
\hline
\end{tabular}


Data hasil validasi maupun respon guru dan peserta didik dianalisis berdasarkan skala linkert. Jarak interval menggunakan rumus :

Jarak interval = jumlah skor maksimal - jumlah skor minimal

jumlah katagori

Untuk melihat penilaian oleh validator materi dapat dilihat pada kriteria validaasi ahli materi seperti pada tabel 6.

Tabel 6. Kriteria validasi ahli materi

\begin{tabular}{cccc}
\hline No & Rentang Nilai & $\begin{array}{c}\text { Persentase } \\
(\%)\end{array}$ & Kriteria \\
\hline 1 & $48,75-60,00$ & $81,25-100,00$ & Sangat Baik \\
2 & $37,50-48,74$ & $62,50-81,24$ & Baik \\
3 & $26,25-37,49$ & $43,75-62,49$ & Tidak Baik \\
4 & $15,00-26,24$ & $25,00-43,74$ & Sangat Tidak Baik \\
\hline
\end{tabular}

Untuk melihat penilaian oleh validator media dapat dilihat pada kriteria validasi ahli media seperti pada tabel 7 .

Tabel 7. Nilai Kriteria validasi ahli media

\begin{tabular}{cccc}
\hline No & Rentang Nilai & $\begin{array}{c}\text { Persentase } \\
(\%)\end{array}$ & Kriteria \\
\hline 1 & $65,00-80,00$ & $81,25-100,00$ & Sangat Baik \\
2 & $50,00-64,99$ & $62,50-81,24$ & Baik \\
3 & $35,00-49,99$ & $43,75-62,49$ & Tidak Baik \\
4 & $20,00-34,99$ & $25,00-43,75$ & Sangat Tidak Baik \\
\hline
\end{tabular}

Kriteria untuk respon guru dan peserta didik pada uji coba kelompok kecil meliputi sangat baik, baik, tidak baik dan sangat tidak baik. Kriteria ini digunakan pada tahap ujicoba kelompok kecil. Kriteria respon guru dan peserta didik tersebut dapat dilihat seperti pada tabel 8.

Tabel 8. Kriteria respon guru dan peserta didik pada uji kelompok kecil

\begin{tabular}{cccc}
\hline No & Rentang Nilai & Persentase $(\%)$ & Kriteria \\
\hline 1 & $39,00-48,00$ & $81,25-100,00$ & Sangat Baik \\
2 & $30,00-38,99$ & $62,50-81,24$ & Baik \\
3 & $21,00-29,99$ & $43,75-62,49$ & Tidak Baik \\
4 & $12,00-20,99$ & $25,00-43,74$ & Sangat Tidak Baik
\end{tabular}

Kriteria untuk respon peserta didik pada ujicoba kelompok besar meliputi sangat baik, baik, tidak baik dan sangat tidak baik. Kriteria tersebut dapat dilihat seperti pada tabel 9.

Tabel 9. Kriteria respon peserta didik uji kelompok besar

\begin{tabular}{cccc}
\hline No & Rentang Nilai & Persentase (\%) & Kriteria \\
\hline 1 & $55,25-68,00$ & $81,25-100,00$ & Sangat Baik \\
2 & $42,51-55,24$ & $62,50-81,24$ & Baik \\
3 & $29,75-42,50$ & $43,75-62,49$ & Tidak Baik \\
4 & $17,00-29,74$ & $25,00-43,74$ & Sangat Tidak Baik \\
\hline
\end{tabular}

\section{HASIL DAN PEMBAHASAN}

Proses validasi merupakan proses yang sangat penting dalam mengembangkan sebuah produk. Validasi media dilakukan oleh seorang ahli dalam bidang media pembelajaran, dilakukan oleh salah satu dosen yang menjadi pengajar di Magister 
Pendidikan IPA Universitas Jambi. Proses validasi media dilaksanakan dalam 2 kali konsultasi, yaitu pada tanggal 16 November 2019, dan pada tanggal 23 November 2019 media dinyatan sudah valid dan layak untuk diujicobakan. Pada validasi pertama, ada beberapa point yang disarankan validator untuk perbaikan media.Secara umum, yang menjadi fokus utama untuk direvisi adalah cover LKPD dan gambar yang ditampilkan dalam media. Pada validasi kedua, secara umum media dinyatakan sudah baik dan layak untuk diuji cobakan. Hasil angket validasi media dapat dilihat pada tabel 10 .

Berdasarkan tabel 10 terlihat total skor LKPD yang dikembangkan adalah 79 dari skor maksimum 80 dengan nilai persentase $98,75 \%$ dengan katagori sangat baik, sehingga produk layak untuk diujicobakan tanpa revisi. Validasi materi dilakukan dalam 2 kali konsultasi, yaitu konsultasi pertama pada tanggal 5 November 2019, dan validasi kedua pada tanggal 12 November 2019. Hal-hal yang diperbaiki dalam proses validasi materi secara umum meliputi perbaikan petunjuk LKPD. Komentar dan saran validator materi pada tahap kedua disajikan pada Tabel11.

Tabel 10. Hasil validasi media LKPD tahap kesatu

\begin{tabular}{|c|c|c|c|}
\hline No & Aspek yang dinilai & Skor & Komentar/Saran \\
\hline & Kelayakan kegrafikan & & \\
\hline 1. & Desain fisik cover sudah didesain dengan baik & 4 & Sudah baik \\
\hline 2. & Desain halaman LKPD sudah didesain dengan baik & 4 & Baik \\
\hline 3. & $\begin{array}{l}\text { Bentuk LKPD sudah ditetapkan sesuai dengan materi } \\
\text { yang akan diajarkan }\end{array}$ & 4 & Baik \\
\hline 4. & $\begin{array}{l}\text { Lay out dan tata letak LKPD sudah didesain dengan } \\
\text { menarik }\end{array}$ & 3 & Baik \\
\hline 5. & $\begin{array}{l}\text { Pemilihan warna pada LKPD sudah ditentukan dengan } \\
\text { baik }\end{array}$ & 4 & Sudah baik \\
\hline 6. & $\begin{array}{l}\text { Objek yang disajikan dalam LKPD dapat mewakili } \\
\text { konsep materi dan didesain dengan baik }\end{array}$ & 4 & Sudah baik \\
\hline 7. & Penggunaaan ilustrasi grafis sudah tepat dan baik & 4 & Baik \\
\hline 8. & Gambar sudah sesuai dengan materi & 4 & Sudah baik \\
\hline 9. & Desain ilustrasi sudah menarik dan komunikatif & 4 & Baik \\
\hline 10. & $\begin{array}{l}\text { Konsistensi penggunaan spasi, judul, dan pengetikan } \\
\text { materi sudah benar dan tepat }\end{array}$ & 4 & Baik \\
\hline 11. & $\begin{array}{l}\text { LKPD sudah dirancang dengan tata letak yang } \\
\text { menarik, mudah dibaca dan digunakan }\end{array}$ & 4 & Baik \\
\hline 12. & $\begin{array}{l}\text { Kesesuaian penggunaaan variasi jenis, ukuran dan } \\
\text { bentuk huruf dalam LKPD sudah benar dan menarik } \\
\text { Kelayakan penyajian }\end{array}$ & 4 & Sudah baik \\
\hline 13. & Urutan penyajian LKPD sudah jelas dan runut & 4 & Sudah baik \\
\hline 14. & $\begin{array}{l}\text { Desain setiap kegiatan yang disajikan mempunyai } \\
\text { tujuan yang jelas }\end{array}$ & 4 & Baik \\
\hline 15. & $\begin{array}{l}\text { Kesinambungan transisi halaman sudah baik dan benar } \\
\text { penulisannya }\end{array}$ & 4 & Baik \\
\hline 16. & $\begin{array}{l}\text { Kemudahan membaca teks atau tulisan sudah didesain } \\
\text { dengan baik }\end{array}$ & 4 & Sudah baik \\
\hline 17. & $\begin{array}{l}\text { Kejelasan petunjuk atau arahan sudah tepat dan baik } \\
\text { Kelayakan bahasa }\end{array}$ & 4 & Baik \\
\hline 18. & $\begin{array}{l}\text { Bahasa yang digunakan sudah sesuai dengan kaidah } \\
\text { EYD }\end{array}$ & 4 & Sudah baik \\
\hline 19. & Bahasa yang digunakan komunikatif dan interaktif & 4 & Baik \\
\hline 20. & Bahasa yang digunakan mudah dipahami peserta didik & 4 & Baik \\
\hline & Total skor & 79 & \\
\hline & Rata-rata skor & 3,95 & \\
\hline & Skor tertinggi & 80 & \\
\hline & Skor terendah & 20 & \\
\hline
\end{tabular}


Validasi materi dilakukan dalam 2 kali konsultasi, yaitu konsultasi pertama pada tanggal 5 November 2019, dan validasi kedua pada tanggal 12 November 2019. Hal-hal yang diperbaiki dalam proses validasi materi secara umum meliputi perbaikan petunjuk LKPD. Komentar dan saran validator materi pada tahap kedua disajikan pada Tabel11.

Tabel 11. Hasil validasi materi LKPD tahap kedua

\begin{tabular}{|c|c|c|c|}
\hline No. & Aspek yang dinilai & Skor & Komentar/Saran \\
\hline & Aspek Isi & & \\
\hline 1. & $\begin{array}{l}\text { Petunjuk penggunaan LKPD untuk guru } \\
\text { dan peserta didik sudah sesuai }\end{array}$ & 4 & Petunjuk sudah komunikatif \\
\hline 2. & $\begin{array}{l}\text { Judul percobaan pada LKPD sudah } \\
\text { sesuai dengan indicator }\end{array}$ & 3 & Judul sesuai indicator \\
\hline 3. & $\begin{array}{l}\text { Teori singkat/fenomena yang disajikan } \\
\text { pada LKPD sesuai dengan } \\
\text { KI/KD/indicator }\end{array}$ & 3 & Teori sudah sesuai indicator \\
\hline 4. & $\begin{array}{l}\text { Materi pada LKPD sesuai dengan } \\
\text { indikator dan tujuan pembelajaran }\end{array}$ & 4 & Materi sudah sesuai indicator \\
\hline 5. & $\begin{array}{l}\text { Kedalaman materi pada LKPD sesuai } \\
\text { dengan } \mathrm{KI} / \mathrm{KD} / \text { Indikator }\end{array}$ & 3 & Materi/teori sudah baik \\
\hline 6. & $\begin{array}{l}\text { LKPD memiliki keutuhan konsep } \\
\text { pembelajaran pada materi Klasifikasi } \\
\text { Mahluk Hidup }\end{array}$ & 4 & $\begin{array}{l}\text { LKPD sudah mewakili klasifikasi } \\
\text { mahluk hidup }\end{array}$ \\
\hline 7. & $\begin{array}{l}\text { LKPD logis jika digunakan dalam proses } \\
\text { pembelajaran IPA di sekolah }\end{array}$ & 4 & Urutan sudah logis/baik \\
\hline 8. & $\begin{array}{l}\text { LKPD runut dalam penyajian alur proses } \\
\text { dan informasi } \\
\text { Isi yang disajikan (penyajian) }\end{array}$ & 4 & Informasi di LKPD sudah cukup \\
\hline 9. & $\begin{array}{l}\text { LKPD memiliki format yang konsisten } \\
\text { dalam penyajiannya }\end{array}$ & 4 & Format sudah konsisten \\
\hline 10. & $\begin{array}{l}\text { LKPD memiliki penjelasan yang relevan } \\
\text { terhadap materi Klasifikasi Mahluk Hidup }\end{array}$ & 3 & Penjelasan sudah relevan \\
\hline 11. & $\begin{array}{l}\text { Tahap kegiatan pada LKPD sudah sesuai } \\
\text { dengan model inkuiri terbimbing }\end{array}$ & 4 & $\begin{array}{l}\text { Tahap kegiatan sudah sesuai } \\
\text { dengan inkuiri terbimbing }\end{array}$ \\
\hline 12. & $\begin{array}{l}\text { Kegiatan yang disajikan menumbuhkan } \\
\text { rasa ingin tahu peserta didik }\end{array}$ & 3 & $\begin{array}{l}\text { Kegiatan menumbuhkan rasa ingin } \\
\text { tahu }\end{array}$ \\
\hline 13. & $\begin{array}{l}\text { Penyajian LKPD dilengkapi dengan } \\
\text { gambar dan lustrasi } \\
\text { Penggunaan bahasa }\end{array}$ & 4 & $\begin{array}{l}\text { Gambar dan ilustrasi sudah } \\
\text { lengkap/baik }\end{array}$ \\
\hline 14. & $\begin{array}{l}\text { Bahasa yang digunakan sesuai dengan } \\
\text { tingkat pemahaman peserta didik }\end{array}$ & 4 & Bahasa sudah baik \\
\hline \multirow[t]{7}{*}{15.} & $\begin{array}{l}\text { Kalimat yang digunakan jelas dan mudah } \\
\text { dimengerti }\end{array}$ & 3 & Kalimat sudah baik \\
\hline & Total skor & \multirow{6}{*}{\multicolumn{2}{|c|}{$\begin{array}{l}54 \\
3,6 \\
60 \\
15 \\
90 \\
\text { Sangat Baik }\end{array}$}} \\
\hline & Rata-rata skor & & \\
\hline & Skor tertinggi & & \\
\hline & Skor terendah & & \\
\hline & Persentase & & \\
\hline & Katagori & & \\
\hline
\end{tabular}

Selanjutnya untuk tampilan hasil pengembangan dan revisi media sebelum dan setelah divalidasi dapat dilihat dalam tabel 12 . 
Tabel 12. Tampilan media sebelum dan setelah revisi

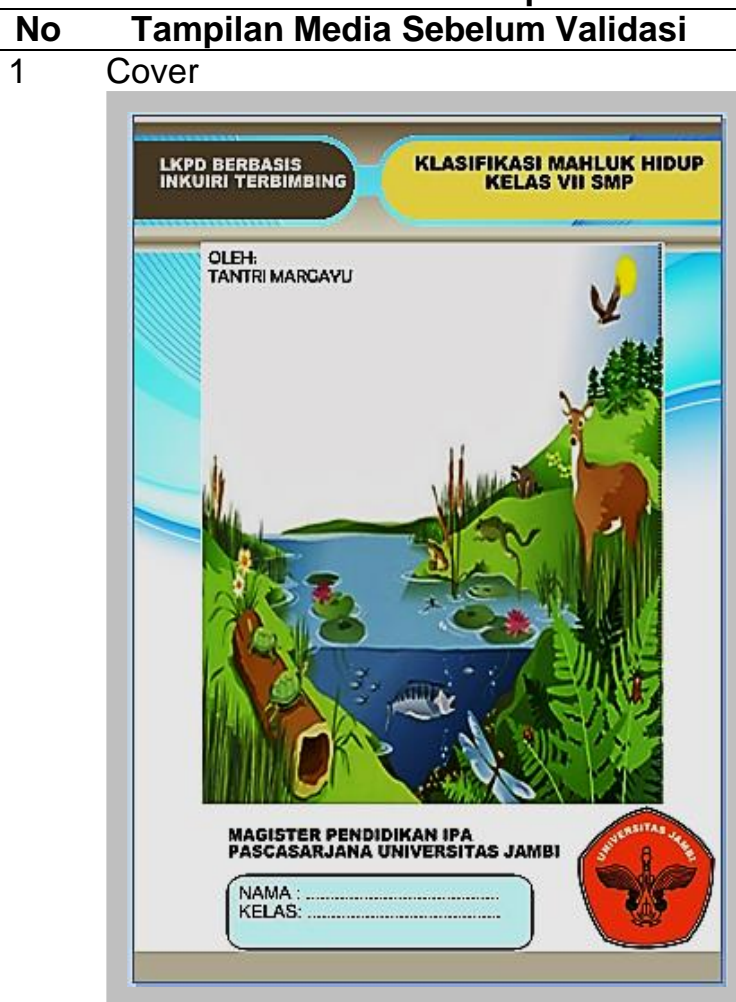

2

Gambar masih berhimpit

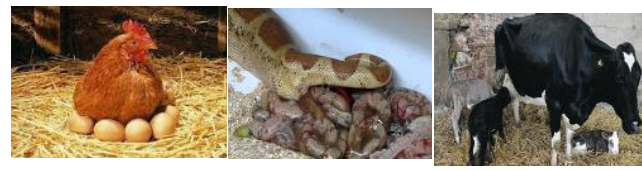

3

Ukuran gambar yang disajikan belum proposional

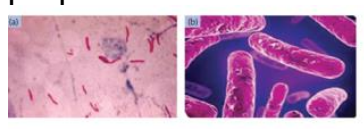

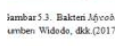
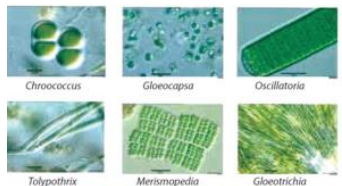

\section{Tampilan Media Setelah Validasi} Cover

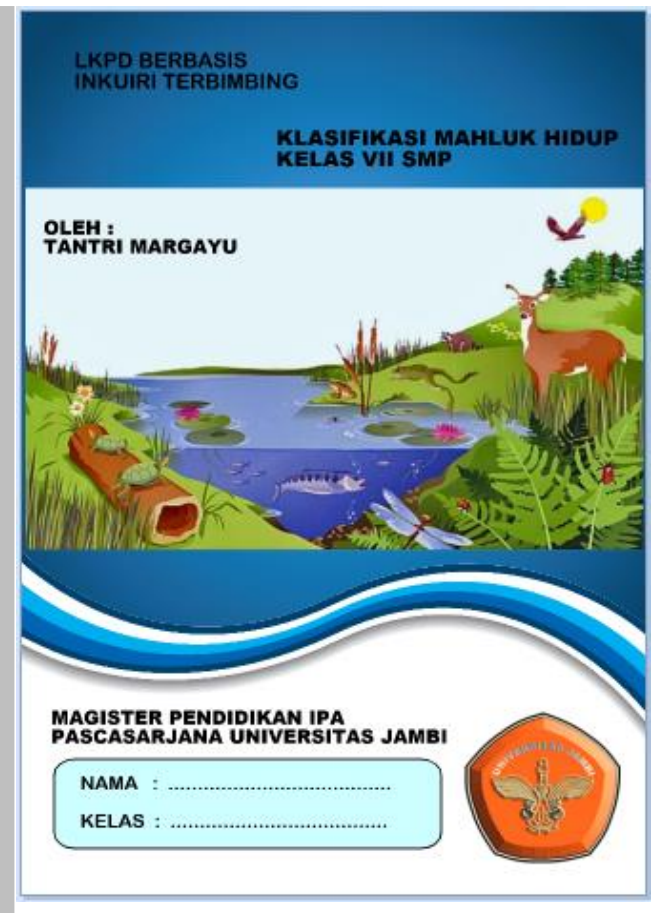

Gambar sudah terpisah, tidak berhimpit
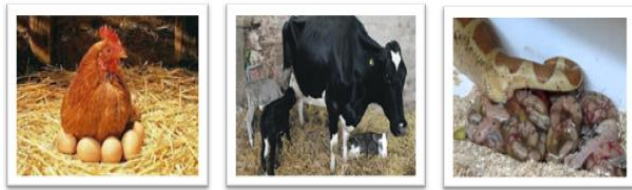

Ukuran gambar yang disajikan sudah proposional

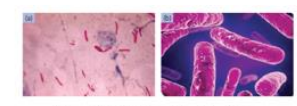

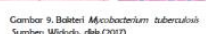

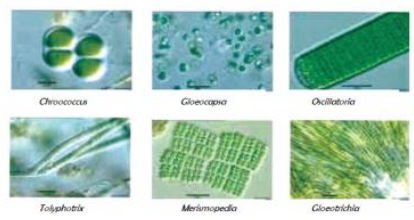

Selanjutnya media yang telah direvisi diujicobakan pada guru dan peserta didik untuk mengetahui respon peserta didik dan guru sebagai pengguna LKPD. Uji coba pada peserta terbagi dalam dua tahap, yaitu uji coba kelompok kecil dan kelompok besar (Tabel 13 dan Tabel 14). Hasil analisis data terhadap respon peserta didik pada uji kelompok kecil dapat dilihat pada tabel 13.

Tabel 13. Hasil analisis data respon peserta didik kelompok kecil

\begin{tabular}{ccccc}
\hline No & Aspek & Jumlah Skor & Persentase (\%) & Kategori \\
\hline 1 & Penyajian & 178 & 92,71 & Sangat baik \\
2 & Bahasa & 90 & 93,75 & Sangat baik \\
& Total & 268 & 93,05 & Sangat baik \\
\hline
\end{tabular}


Hasil analisis data terhadap respon peserta didik pada uji kelompok besar dapat dilihat pada tabel 14 .

Tabel 14. Hasil analisis data respon peserta didik kelompok besar

\begin{tabular}{ccccc}
\hline No & Aspek & Jumlah Skor & Persentase (\%) & Kategori \\
\hline 1 & Penyajian & 524 & 81,87 & Sangat baik \\
2 & Bahasa & 271 & 84,69 & Sangat baik \\
3 & Kegrafikan & 378 & 94,50 & Sangat baik \\
& Total & 1173 & 86,25 & Sangat baik \\
\hline
\end{tabular}

Untuk melihat kelayakan media secara praktis juga dilakukan uji Kappa dari data respon peserta didik kelompok besar. Terlebih dahulu data dibagi menjadi 2 kelompok, kelompok pertama data dari responden nomor 1-10 dan kelompok kedua data responden nomor 11-20. Nilai rata-rata dari masing-masing kelompok kemudian diuji Kappa dengan program SPSS, didapat hasil pada Tabel 15 berikut

Tebel 15. Hasil uji Kappa (Symmetric Measures)

\begin{tabular}{|c|c|c|c|c|c|}
\hline & & Value & $\begin{array}{c}\text { Asymp. } \\
\text { Std. Error } \\
\end{array}$ & $\begin{array}{c}\text { Approx. } \\
\mathrm{T}^{\mathrm{b}}\end{array}$ & Approx. Sig. \\
\hline Interval by Interval & Pearson's R & ,992 & ,004 & 22,115 &, $000^{\circ}$ \\
\hline Ordinal by Ordinal & $\begin{array}{l}\text { Spearman } \\
\text { Correlation }\end{array}$ & 963 & ,056 & 10,101 &, $000^{\circ}$ \\
\hline Measure of Agreement & Kappa & ,647 & 168 & 4,969 & ,000 \\
\hline $\mathrm{N}$ of Valid Cases & & 10 & & & \\
\hline
\end{tabular}

Nilai Kappa yang dipakai untuk menentukan kekuatan kesepakatan merupakan suatu tes diagnosik yang dianjurkan oleh Landis dan Koch. Dengan patokan kekuatan kesepakatan $<0,00$ sangat jelek, 0,00 $-0,21$ jelek, 0,22 $-0,40$ kurang, 0,41-0,60 sedang, 0,61 -0,80 baik, 0,81-1,00 sangat baik. Nilai Kappa yang dapat diandalkan untuk dipakai adalah antara 0,61 - 1,00 (Mau. 2014). Hasil koefisien uji Kappa yang didapat dari uji kelompok besar dari tabel 4.15 didapat nilai 0,647 berarti nilai tersebut dapat diandalkan dengan interpretasi Kappa baik. Hasil analisis data respon guru yang dilakukan oleh dua orang guru IPA SMPN 10 Kota Jambi dapat dilihat pada tabel 15.

Tabel 15. Hasil analisis data angket respon guru

\begin{tabular}{ccccc}
\hline No & Aspek & Jumlah Skor & Persentase (\%) & Kategori \\
\hline 1 & Penyajian & 62 & 96,87 & Sangat baik \\
2 & Bahasa & 32 & 100 & Sangat baik \\
& Total & 94 & 97,92 & Sangat baik \\
\hline
\end{tabular}

\section{KESIMPULAN}

Berdasarkan hasil validasi oleh ahli media dan materi serta ujicoba pada guru dan siswa maka produk LKPD berbasis inkuiri terbimbing pada pokok bahasan klasifikasi mahluk hidup untuk kelas VII SMP dilakukan dengan menggunakan model ADDIE layak dipergunakan dalam pembelajaran. Ahli media memberikan nilai kelayakan 98,75\%. dan ahli materi 90,00\%, dengan demikian LKPD masuk katagori sangat baik. Respon guru terhadap LKPD mendapatkan nilai persentase 97,92\% dengan katagorisangatbaik. dan respon peserta didik produk LKPD menghasilkan nilai persentase $93,05 \%$ dengan katagori sangat baik. 


\section{DAFTAR PUSTAKA}

Branch, R.M. 2009. Instructional Design: The ADDIE Aproach. New York. Springer Science + Busines Media, LLC.

Dewi, R., Budiarti, R. S., \& Aina, M. (2017). Pengembangan lembar kegiatan peserta didik (Ikpd) bermuatan pendidikan karakter dengan model pembelajaran guided inquiry pada materi bakteri bagi siswa kelas $x$ sekolah menengah atas. BIODIK, 3(1), 17-26.

Eggen, P.D. \& Kauchak, D.P. 2012. Strategi dan Model Pembelajaran (terjemahan). Jakarta: PT Indeks. Hal: 175-215

Nuraini, I. 2014. Penggunaan LKPD Berbasis Guided Inquiry Untuk SMA Kelas XI pada Konsep Sistem Sirkulasi. Skripsi. Jurusan Pendidikan ilmu Pengetahuan Alam Fakultas IImu Tarbiyah dan Keguruan Universitas Islam Negeri Syarif Hidayatullah Jakarta. Hal: 71

Rokhmah, A. dan Madlazim. 2015.Pengembangan Lembar Kerja Peserta didik (LKS) Berbasis Inkuiri Terbimbing Untuk Melatihkan Keterampilan Peserta didik Dalam Melakukan Eksperimen Pada Materi Ajar Sumber Energi Terbarukan. Jurnal Inovasi Pendidikan Fisika (JIPF). Jurusan Fisika, Fakultas Matematika dan IImu Pengetahuan Alam, Universitas Negeri Surabaya, 4(2), 88-91.

Sadikin, A. (2015). Hubungan EQ (Emotional Quotient) dengan hasil belajar mahasiswa biologi semester Ganjil Tahun Ajaran 2014/2015. BIODIK, 1(1).

Sumiati dan Asra. 2007. Metode Pembelajaran. Bandung. CV Wacana Prima. Hal: 171.

Mau. 2014. Koefesien Kappa sebagai Indeks Kesepakatan Hasil Diognosis

Mikroskopis Malaria di Kabupaten Belu Nusa Tenggara Timur. Buletin Penelitian Kesehatan. 43 (2), Hal. 117-124.

Zubaidah S., Mahanal S., Yuliarti. 2017. Buku Guru IImu Pengetahuan Alam. Kementerian Pendidikan dan Kebudayaan Republik Indonesia. Jakarta. Hal:815. 